\title{
CORRIGENDUM
}

\section{First archaeointensity reference paleosecular variation curve for South America and its implications for geomagnetism and archaeology - Corrigendum}

Avto Goguitchaichvili, Catriel Greco, Rafael Garcia Ruiz, Lucas Pereyra Domingorena, Ruben Cejudo, Juan Morales, Claudia Gogorza, Cristina Scattolin, Myriam Tarragó

DOI: https://doi.org/10.1017/qua.2018.119; Published online by Cambridge University Press 1 March 2019

Figure 6 was printed incorrectly in the original publication of Goguitchaichvili et al. (2019). The correct Figure 6 is reproduced below.

The authors apologize for this error.

\section{Reference}

Goguitchaichvili, A., Greco, C., Garcia Ruiz, R., Pereyra Domingorena, L., Cejudo, R., Morales, Gogorza, C., et al (2019). First archaeointensity reference paleosecular variation curve for South America and its implications for geomagnetism and archaeology. Quaternary Research, 92(1), 81-97.

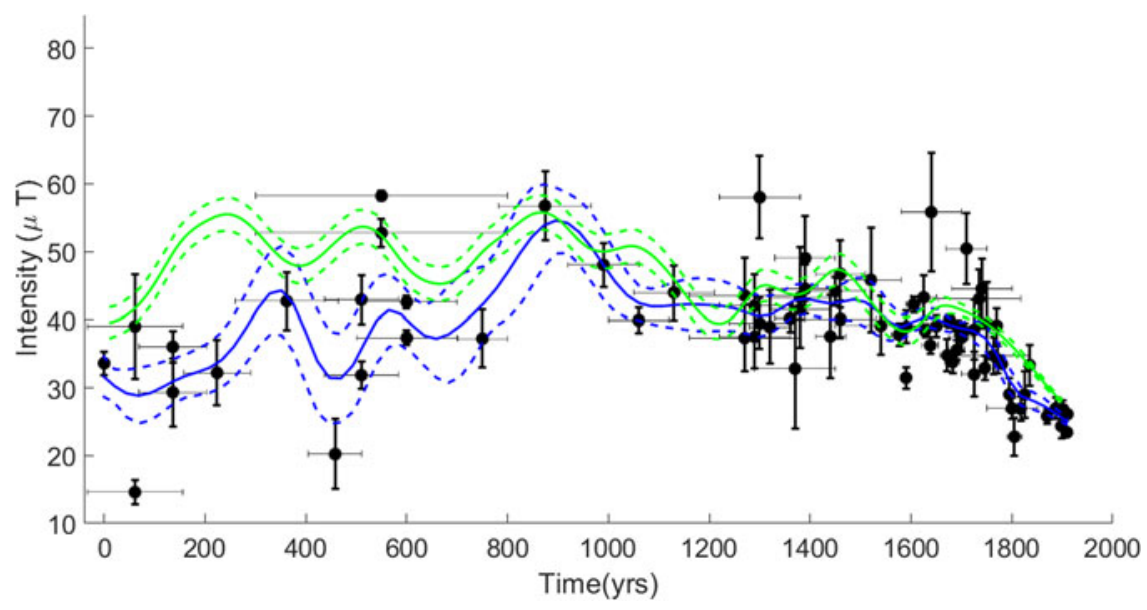

Figure 6.

Cite this article: Goguitchaichvili, A., Greco, C., Ruiz, R. G., Domingorena, L. P., Cejudo, R., Morales, J., Gogorza, C., Scattolin, C., Tarragó, M. 2020. First archaeointensity reference paleosecular variation curve for South America and its implications for geomagnetism and archaeology - Corrigendum. Quaternary Research, 98, 103. https:// doi.org/10.1017/qua.2020.17 